\title{
Workshop Peran E-Commerce Terhadap UMKM di Purbalingga
}

\author{
Indra Sukma Subagio ${ }^{1)}$, Esti Saraswati ${ }^{2)}$, Kartika Dwi Chandra Sari ${ }^{3)}$ \\ ${ }^{12)}$ Prodi Akuntansi, Fakultas Ilmu Sosial, Universitas Harapan Bangsa, Banyumas, Indonesia \\ ${ }^{3)}$ Prodi Manajemen, Fakultas Ilmu Sosial, Universitas Harapan Bangsa, Banyumas, Indonesia \\ Corresponding Author: Indra Sukma Subagio, indrasukmasubagio@uhb.ac.id
}

\begin{abstract}
Abstrak: Salah satu masalah yang dialami penggiat UMKM di RKB Purbalingga adalah pemasaran produk yang kurang maksimal. Banyak dari mereka sudah menggunakan e-commerce, namun tidak serta merta membuat penjualan meningkat. Tujuan pengabdian masyarakat adalah untuk meningkatkan pengetahuan penggiat UMKM RKB Purbalingga tentang peran e-commerce dalam meningkatkan kinerja. Metode pengabdian yang dilakukan adalah dengan melakukan workshop tentang peran ecommerce terhadap kinerja UMKM. Kegiatan pengabdian masyarakat ini dilaksanakan pada hari Selasa 29 Desember 2020 pukul 09.00-01.00 WIB. Penggunaan pretest dan posttest dilakukan untuk mengukur keberhasilan dari kegiatan ini. Terdapat peningkatan pemahaman sebesar $28 \%$ setelah dilakukan perbandingan antara pretest dan posttest, yang berarti bahwa penggiat UMKM di Purbalingga semakin memahami bagaimana e-commerce dapat meningkatkan omzet usaha mereka.
\end{abstract}

Kata Kunci: E-commerce, Kinerja UMKM

\begin{abstract}
One of the problems experienced by MSME owners at RKB Purbalingga is product marketing that is not optimal. Many of them are already using e-commerce, but that doesn't necessarily increase sales. The purpose of community service is to increase the knowledge of MSME owners at RKB Purbalingga about the role of e-commerce in improving performance. The service method that is carried out is by conducting a workshop on the role of e-commerce on the performance of MSMEs. This community service activity was held on Tuesday 29 December 2020 at 09.00-01.00 WIB. The use of pretest and posttest was carried out to measure the success of this activity. There was an increase in understanding of $28 \%$ after a comparison between the pretest and posttest was made, which means that MSMEs owners at RKB Purbalingga increasingly understand how e-commerce can increase their business turnover.
\end{abstract}

Keywords: E-commerce, MSME's performance

\section{Pendahuluan}

UMKM merupakan salah satu tulang punggung ekonomi nasional. Selain menjadi penyumbang PDB terbesar, UMKM juga mempunyai peran lain sebagai unit yang mampu mengurangi jumlah pengangguran yang ada di Indonesia. Dengan adanya ledakan jumlah penduduk yang meningkat sangat pesat, maka peran UMKM akan bertambah krusial di beberapa waktu yang akan datang. Potensi besar itu harus mampu dimaksimalkan oleh para pelaku usaha dengan dorongan yang dilakukan pemerintah.

Target pemerintah untuk dapat mencapai pendapatan menengah pada tahun 2025 mengharuskan Indonesia untuk meningkatkan pertumbuhan ekonominya menjadi 7\% (Deloitte Access Economics, 2015). Salah satu cara yang bisa dilakukan pemerintah untuk mencapai itu adalah dengan memaksimalkan peran UMKM dengan penambahan kurang lebih sebesar $2 \%$. 
Cara tercepat mencapai target itu dengan cara memanfaatkan teknologi informasi untuk perkembangan UMKM, salah satunya menggunakan media e-commerce.

Senada dengan itu, menurut Kemp (2020) potensi e-commerce masih sangat terbuka lebar karena makin banyak orang melakukan kegiatannya secara online daripada sebelumnya. Lebih lanjut Kemp (2020) memaparkan bahwa terdapat 4,5 triliun orang di dunia yang menggunakan internet. Hal ini merupakan peluang emas yang bisa dimaksimalkan oleh penggiat UMKM, alih-alih bersaing langsung dengan perusahaan besar di media konvensional, mereka bisa memaksimalkan media elektronik.

Salah satu media elektronik yang paling sering digunakan dalam memasarkan produk adalah e-commerce. Menurut Khan (2016) e-commerce adalah penggunaan internet dalam aktivitas penjualan dan pembelian barang atau jasa. Lebih lanjut Laudon \& Guercio (2018) menjelaskan 8 hal yang menyebabkan e-commerce disukai oleh masyarakat. Delapan hal tersebut adalah ubiquity (tersedia dimanapun), menjangkau pasar global, sistem terstandar, informasi yang lebih lengkap, interaktif, akurat, spesifik dan fleksibel, dan melibatkan semua pihak. Menurut Katrina B. \& Benedict L (2018) ada empat hal yang mendasari perkembangan e-commerce.

Pertama adalah meningkatnya jumlah middle clas yang mencapai 52 juta jiwa, lebih lanjut masyarakat middle class ini menyumbang $43 \%$ dari total konsumsi rumah tangga (The World Bank, 2017). Kedua, meningkatnya penggunaan smart phone dan kemudahan jangkauan internet sehingga memudahkan masyarakat dari berbagai kelas sosial ekonomi dalam mengakses toko online, market place, media sosial, dll.

Ketiga adalah tingginya pertumbuhan perusahaan fintech dan opsi pembayaran alternatif. Seperti yang kita tau, tren cashless sudah menjadi gaya hidup anak muda dalam melakukan kegiatan belanja (Putera, 2019). Keempat, investasi teknologi e-commerce di Indonesia. Tingginya investasi pada platforms e-commerce ini memberikan dampak yang besar bagi perkembangan e-commerce (Reuters Staff, 2016).

Beberapa penelitian telah dilakukan mengenai adopsi e-commerce untuk UMKM, terutama di negara berkembang (Kurnia et. al., 2015; Khan, 2016; Rahayu \& Day, 2017). Di Indonesia e-commerce bukan merupakan hal baru, namun demikian, penerapannya di kalangan UMKM masih bersifat terbatas atau masih dalam tahap awal (Rahayu \& Day, 2017). Hanya UMKM yang masuk menjadi binaan instasi-instansi besar saja yang cenderung menggunakan dan memanfaatkan e-commerce. Padahal dengan tingginya konsumen kelas menengah di Asia yang diperkirakan akan menembus angka 4,9 miliar jiwa pada tahun 2030 (Deloitte Access Economics, 2015), maka area ini merupakan ladang subur yang harus terus dimaksimalkan oleh pemerintah sebagai regulator, dan UMKM sebagai pelaku usaha.

Sayangnya, faktor-faktor yang bisa meningkatkan kinerja UMKM belum tersebar secara merata di Indonesia. Masih banyak UMKM yang menggunakan pendekatan tradisional untuk menjalankan unit usahanya. Produksi yang masih menggunakan alat-alat tradisional, pemasaran yang masih bergantung kepada selebaran dan web pemerintah daerah, sehingga potensi yang sebenarnya sangat besar jadi sulit untuk diraih. Kurangnya pelatihan-pelatihan yang dilakukan baik oleh pemerintah, LSM, maupun institusi pendidikan menjadi beberapa akibat dari kurang maksimalnya potensi UMKM dicapai.

Salah satu masalah utama yang dihadapi UMKM di Purbalingga adalah pengetahauan yang mendasar serta belum menyeluruh terkait dengan $e$-commerce. Dalam wawancara secara acak terhadap beberapa penggiat UMKM di Purbalingga, mereka mengeluhkan bahwa penggunaan e-commerce sudah dilakukan, namun belum memberikan hasil yang signifikan terhadap omzet yang dihasilkan. Lebih lanjut, mereka bercerita media yang digunakan dalam memasarkan produknya hanya sebatas facebook, instagram, serta beberapa marketplace. 
Namun, mereka hanya menggunakan fitur-fitur default dari media-media tersebut karena kurangnya pengetahuan terhadap beberapa fitur yang masih bisa dieksplorasi sehingga mampu memberikan dampak yang lebih signifikan.

Tujuan dilaksanakannya pengabdian kepada masyarakat ini untuk memberi pengtahuan yang lebih menyeluruh kepada UMKM di Purbalingga dalam memaksimalkan peran $e$ commerce untuk meningkatkan produktivitas dan profitabilitasnya. Dengan workshop ini diharapkan UMKM di Purbalingga dapat meningkatkan penjualan, produktivitas dan profitabilitas mereka melalui penggunaan $e$-commerce.

\section{Metodologi}

Metode pemecahan yang dilakukan adalah dengan memberikan materi terkait dengan peran e-commerce dalam meningkatkan kinerja UMKM dalam bentuk workshop yang di dalamnya dilengkapi dengan adanya pretest dan posttest, sehingga bisa diketahui sejauh mana peningkatan kemampuan peserta workshop sebelum dan sesudah diadakannya workshop.

\section{A. Pra Kegiatan}

Prosedur yang dilakukan untuk mewujudkan tujuan dari Program pelaksanaan Pengabdian Kepada Masyarakat di UMKM RKB Purbalingga antara lain:

1. Melakukan observasi dan wawancara terhadap mitra mengenai permasalahan yang dihadapi oleh UMKM RKB Purbalingga.

2. Identifikasi masalah melalui wawancara dengan pengelola UMKM dan Narasumber yang berkompeten untuk memperoleh data dan solusi yang tepat guna penyelesaian masalah.

3. Menentukan tanggal pelaksanaan dan waktu kegiatan.

4. Melakukan perijinan kepada instansi-instansi terkait sehingga kegiatan ini bisa berjalan dengan lancar dan aman.

5. Penyusunan solusi permasalahan melalui studi literasi dan pembuatan kuesioner pretest dan posttest tentang pemahaman e-commerce.

6. Pembuatan berkas-berkas pendukung kegiatan.

\section{B. Tahap Pelaksanaan}

Kegiatan pengabdian kepada masyarakat dilakukan dalam bentuk workshop untuk menjawab permasalah yang terjadi, yaitu sudah menggunakan e-commerce namun belum memberikan dampak yang signifikan terhadap omzet penjualan. Berikut ini dijelaskan waktu, tempat, dan rencana pelaksanaannya.

1. Kegiatan pengabdian kepada masyarakat yang berbentuk workshop ini dilakukan di Griya UMKM Purbalingga yang beralamat di Jalan Raya Mayjen Sungkono, Karangpoh Kulon, Selabaya, Kec. Kalimanah, Kabupaten Purbalingga, Jawa Tengah 53371. Kegiatan ini dilakukan oleh 2 dosen akuntansi dan 1 dosen manajemen serta bantuan 3 orang mahasiswa. Untuk waktu pelaksanaan dilakukan pada hari Selasa, 29 Desember 2020 dimulai pada pukul $09.00-01.00 \mathrm{WIB}$.

2. Dalam proses pelaksanaan kegiatan, disusunlah rencana kegiatan terkait dengan pemberian workshop untuk meningkatkan pengetahuan penggiat UMKM yang terdaftar di RKB Purbalingga. Berikut adalah jadwal workshop dan alokasi pelaksanaan peran e-commerce terhadap UMKM di Purbalinga. 
Tabel 1. Materi dan Jadwal Workshop

\begin{tabular}{ll}
\hline Jenis Kegiatan & Workshop peran e-commerce terhadap UMKM di Purbalingga \\
\hline Pendaftaran & Esti Saraswati, S.E., M.Si. dan Mahasiswa \\
MC & Kartika Dwi Chandra Sari S.E., MBA. \\
Sambutan & 1. Alfizi, S.E., MM. (Dekan FIS) \\
& 2. Istriyati (Sekdin Diskopukm Purbalingga) \\
Pra Workshop & Pengisian kuesioner pretest \\
Pemateri & Indra Sukma Subagio, S.E., M.Ak. \\
& (Peran E-Commerce Terhadap UMKM) \\
Pasca Materi & Pengisian kuesioner posttest \\
\hline
\end{tabular}

Tabel 2. Alokasi Waktu Kegiatan

\begin{tabular}{|c|c|c|c|c|c|}
\hline \multirow{2}{*}{\multicolumn{2}{|c|}{ Kegiatan }} & \multicolumn{4}{|c|}{ Tahun $2020 / 2021$} \\
\hline & & Oktober & November & Desember & Januari \\
\hline 1. & Observasi permasalahan & $\sqrt{ }$ & & & \\
\hline 2. & Pembuatan proposal & $\sqrt{ }$ & & & \\
\hline 3. & Perijinan dan survey & & $\sqrt{ }$ & & \\
\hline 4. & Perancangan & & $\sqrt{ }$ & & \\
\hline 5. & Pelaksanaan & & & $\sqrt{ }$ & \\
\hline 6. & Pelaporan & & & $\sqrt{ }$ & $\sqrt{ }$ \\
\hline
\end{tabular}

\section{Observasi Hasil Workshop}

Setelah berlangsungnya workshop, dilakukan observasi terhadap hasil pengujian pretest dan posttest terhadap respon penggiat UMKM. Observasi dilakukan oleh penulis dan dibantu oleh mahasiswa dengan menggunakan program software computer, sehingga menghasilkan hasil yang paling jelas.

\section{Hasil dan Pembahasan}

\section{A. Pelaksanaan Kegiatan dan Hasil}

Sesuai dengan rencana awal, kegiatan workshop peran e-commerce terhadap kinerja UMKM dilakukan pada hari Selasa, 29 Desember 2020. Dimulai pada pukul 09.00 WIB dengan presensi peserta workshop yang dilakukan oleh oleh mahasiswa dan didampingi oleh dosen. Pendaftaran ini dibuka mulai dari pukul 09.00 sampai dengan pukul 9.30 WIB.

Total peserta yang menghadiri acara workshop \pm 15 Orang, hal ini berkaitan dengan adanya pandemi covid-19 yang mengharuskan adanya physical distancing sehingga mengingat terbatasnya venue yang digunakan maka peserta harus dibatasi. Protokol kesehatan diperhatiakan dengan sangat detail, peserta sebelum memasuki venue acara harus cuci tangan dengan sabun maupun menggunakan hand sanitizer, selain itu peserta diwajibkan mengenakan masker selama acara berlangsung.

Acara dimulai pukul 10.00 WIB dengan sambutan yang dilakukan oleh dekan Fakultas Ilmu Sosial, Universitas Harapan Bangsa, Alfizi, S.E., M.M., yang menyampaikan betapa pentingnya peran $e$-commerce untuk perkembangan UMKM karena adanya pergeseran perilaku konsumen. Lebih lanjut disampaikan bahwa dengan adanya kegiatan ini bisa mendorong kerjasama yang lebih lanjut antara instansi pendidikan dan penggiat UMKM sehingga terjadi kerjasama yang berkesinambungan antara keduanya. Kemudian acara dilanjutkan oleh sambutan dari Sekretaris Dinas Koperasi dan UMKM Kabupaten Purbalingga, yang menyambut gembira adanya kegiatan ini, sehingga Dinas Koperasi dan UMKM Kabupaten Purbalingga merasa terbantu dalam melakukan pendampingan terhadap perkembangan UMKM di Kabupaten Purbalingga. 
Sebelum penyampaian materi workshop disampaikan, dibagikan kuesioner pretest kepada 15 orang peserta untuk mengetahui seberapa jauh pengetahuan peserta terkait dengan e-commerce dan perannya terhadap kinerja UMKM. Kemudian dilanjutkan dengan pemaparan materi terkait dengan tema utama, selama pemaparan materi terlihat peserta memerhatikan dengan sangat antusias, bahkan setelah materi selesai disampaikan peserta masih antusias untuk melakukan diskusi terkait materi dan implementasi yang sudah mereka lakukan.

Sebelum acara ditutup, dibagikan kembali kuesioner posttest untuk mengukur adanya perubahan pemahaman yang dialami oleh peserta workshop. Tabel 3 menunjukan hasil pretest dan posttest yang dilakukan. Acara ditutup dengan foto bersama antara tim dosen yang bertugas dan peserta workshop. Berikut ini adalah hasil dokumentasi berlangsungnya acara workshop.

Tabel 3. Hasil Pretest dan Posttest

\begin{tabular}{lc}
\hline Kegiatan & Hasil \\
\hline Pretest & 7,57 \\
Posttest & 9,64 \\
Presentase beda & $27,36 \%$ \\
\hline
\end{tabular}

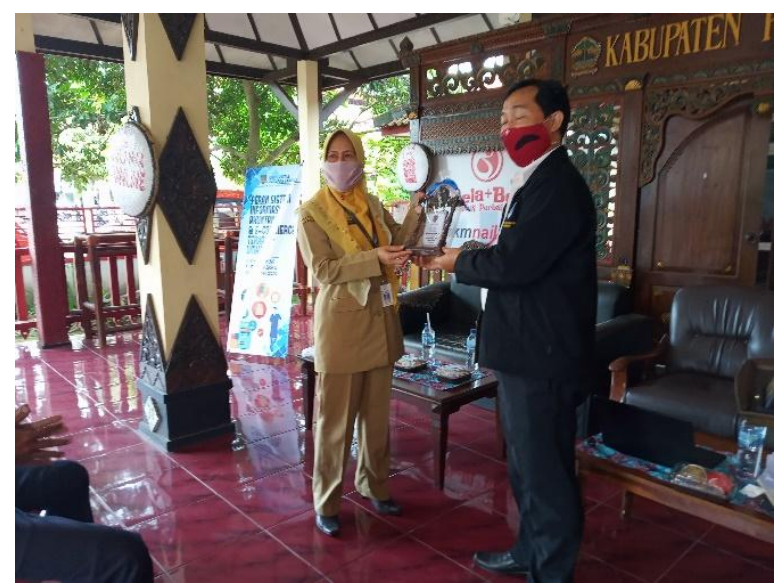

Gambar 1. Serah terima kenang-kenangan

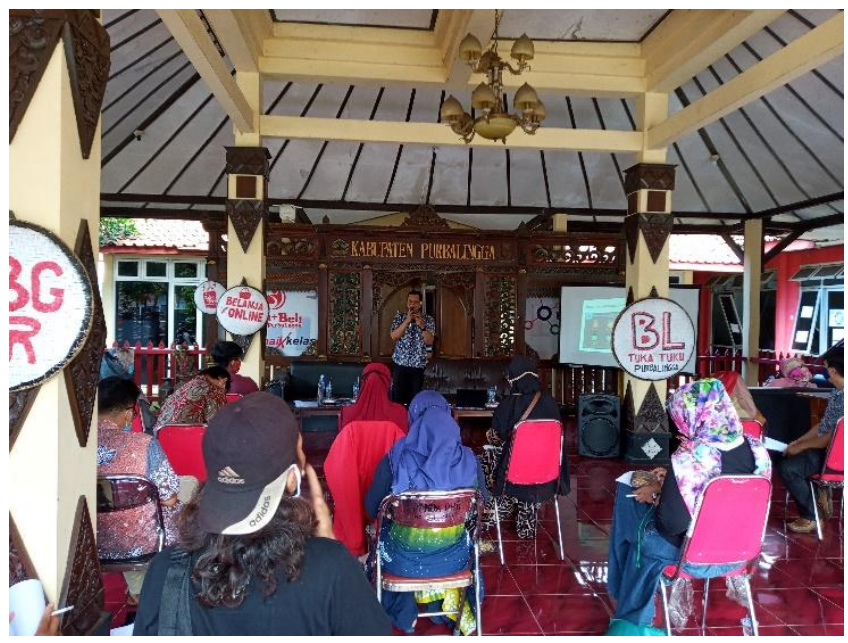

Gambar 2. Penyampaian materi workshop 


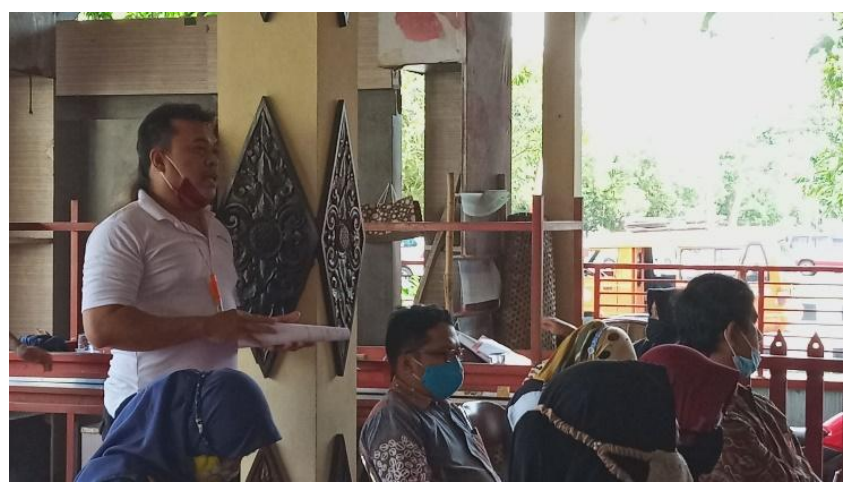

Gambar 3. Peserta bertanya terkait materi workshop

\section{B. Pembahasan}

Beberapa penelitian memberikan gambaran nyata peran e-commerce terhadap UMKM (Jahanshahi, Zhang, \& Brem, 2013; Savrul, Incekara, \& Sener, 2014). Peran e-commerce yang paling nyata untuk penggiat UMKM adalah mengurangi biaya pemasaran, meningkatkan brand image, lebih mudah dicapai oleh end user, meningkatkan pelayanan terhadap konsumen, dll. (Jahanshahi et al., 2013). Hal-hal tersebut yang mendasari bahwa seharusnya e-commerce memberikan dampak yang positif bagi perkembangan UMKM. Namun pada kenyataannya masih banyak UMKM yang belum bisa mengkases maupun memanfaatkan peran e-commerce tersebut dalam meingkatkan omzet usaha mereka. Salah satunya adalah penggiat UMKM yang ada di Purbalingga.

Berdasarkan hasil pengujian pretest, terlihat bahwa peserta workshop rata-rata mendapatakan skor 7,57. Hasil ini sebenernya cukup menggembirakan karena pada dasarnya penggiat UMKM di Purbalingga memang sudah menggunakan e-commerce dalam memasarkan produknya. Disisi lain, pemahaman saja ternyata belum cukup dalam meningkatkan omzet penjualan mereka. Dalam wawancara terpisah, salah satu peserta menceritakan bahwa kendala mereka adalah kurangnya pemahaman yang lebih komprehensif tentang e-commerce dan kekurangan sumber daya dalam memanfaatkan e-commerce secara lebih maksimal.

Selama diadakannya workshop, peserta memerhatikan materi yang disampaikan dengan seksama. Hal itu terekam dalam dokumentasi yang dilakukan dan terlihat dalam beberapa pertanyaan yang dilontarkan saat sesi diskusi. Banyak pertanyaan-pertanyaan yang muncul terkait bagaimana memaksimalkan penggunaan $e$-commerce sehingga menghasilkan manfaat yang semaksimal mungkin. Salah satunya adalah pertanyaan tentang pemanfaatan $e$-commerce dalam hal mengelola informasi yang berguna bagi seller seperti jumlah transaksi, dan customer behaviour.

Pertanyaan-pertanyaan tersebut membuka dimensi baru bagi penggiat UMKM di Purbalingga bahwa e-commerce bukan lagi hanya sekedar menginput produk ke dalam marketplace dan menunggu pembeli datang. Terdapat beberapa sumber informasi yang bisa mereka gunakan untuk menganalisa perilaku konsumen, jumlah viewer produk mereka, produk mana saja yang paling banyak dilihat oleh konsumen, dari mana saja asal konsumen mereka, serta beberapa informasi tambahan lain.

Setelah penyampaian materi, dibagikan kuesioner posttest kepada peserta workshop. Setelah dilakukan penghitungan hasil, rata-rata nilanya menjadi 9,64, yang berarti ada peningkatan pemahaman terkait peran e-commerce terhadap kinerja UMKM sebesar 27,36\%. Hal ini mengindikasikan bahwa penyampaian materi memberikan hasil yang positif, karena adanya peningkatan nilai rata-rata setelah peserta workshop mendapatkan materi tentang peran 
e-commerce. Selain itu, penggiat UMKM di Purbalingga juga mengharapakan adanya workshop -workshop susulan yang lebih bersifat teknikal, sehingga mampu memberikan pengetahuan baru terhadap mereka tentang penggunaan $e$-commerce yang bisa meningkatkan omzet dari usaha mereka.

\section{Simpulan}

Secara umum, penggiat UMKM di Purbalingga sudah menggunakan e-commerce dalam memasarkan produk mereka, namun terkesan belum maksimal dan hanya sebatas mencoba saja. Banyak dari mereka yang hanya memasukan produk mereka ke dalam e-commerce tanpa mengelola lebih lanjut. Padahal banyak sekali informasi berguna yang bisa digunakan mereka untuk lebih memaksimalkan pemasaran dan penjualan produk mereka.

Setalah adanya workshop terjadi peningkatan pemahaman sebesar $27,36 \%$ yang berarti mereka sudah lebih memahami bagaimana memanfaatkan dan memaksimalkan peran $e$ commerce dalam meningkatkan pemasaran dan penjualan produk mereka. Benefit-benefit seperti mudahnya pengelolaan transaksi, backlog transaksi, kebiasaan pelanggan dalam berbelanja, aftersales yang baik, dan pemasaran yang lebih luas memberikan pandangan baru bagi mereka bagaimana memaksimalkan peran $e$-commerce.

\section{Ucapan Terima Kasih}

Tim pengabdian masyarakat mengucapakan terima kasih terhadap pihak-pihak yang telah membantu sehingga kegiatan ini bisa berlangsung dengan lancar, aman, dan tanpa hambatan apapun. Pertama, Yayasan Pendidikan Dwi Puspita atas hibah internal yang sudah diberikan sehingga tim peneliti mampu melaksanakan kegiatan ini. Kedua, Universitas Harapan Bangsa dan Fakultas Ilmu Sosial yang sudah memberikan kesempatan dan bantuan baik secara moril dan materiil. Kepada Dinas Koperasi dan UKM, Kesbangpol dan Bappelitbangda Kabupaten Purbalingga atas bantuan sarana dan ijin yang sudah diberikan. Terakhir, terima kasih untuk penggiat UMKM RKB Purbalingga yang sudah meluangkan waktu, pikiran dan tenaganya untuk menghadiri dan bekerja sama sehingga acara ini bisa berlangsung. Semoga hasil dari pengabdian ini, baik kegiatan dan artikel yang diterbitkan mampu memberikan manfaat kepada para pelaku dan pembacanya.

\section{Daftar Pustaka}

Deloitte Access Economics. (2015). UKM pemicu kemajuan Indonesia.

Jahanshahi, A. A., Zhang, S. X., \& Brem, A. (2013). E-commerce for SMEs: Empirical insights from three countries. Journal of Small Business and Enterprise Development, 20(4), 849865. https://doi.org/10.1108/JSBED-03-2012-0039

Katrina B. \& Benedict L. (2018). What's Driving Indonesian Ecommerce Growth? Retrieved February 2, 2021, from https://janio.asia/articles/what-s-driving-indonesian-ecommerce-in-2018/

Kemp, S. (2020). Digital 2020: 3.8 Billion People Use Social Media. Retrieved January 26, 2020, from https://wearesocial.com/blog/2020/01/digital-2020-3-8-billion-people-usesocial-media

Khan, A. G. (2016). Electronic Commerce: A Study on Benefits and Challenges in an Emerging Economy. Type: Double Blind Peer Reviewed International Research Journal Publisher: 
Global Journals Inc, 16(1).

Kurnia, S., Choudrie, J., Mahbubur, R. M., \& Alzougool, B. (2015). E-commerce technology adoption: A Malaysian grocery SME retail sector study. Journal of Business Research, 68(9), 1906-1918. https://doi.org/10.1016/j.jbusres.2014.12.010

Laudon, K. C., \& Guercio, C. (2018). E-Commerce 2018: Business, Technology, Society. In E-commerce 2018.

Putera, I. (2019). Indonesia's e-wallet race is heating up. Here are the main players. Retrieved February 2, 2021, from https://news.finchcapital.com/post/102fhye/indonesias-e-walletrace-is-heating-up-here-are-the-main-players

Rahayu, R., \& Day, J. (2017). E-commerce adoption by SMEs in developing countries: evidence from Indonesia. Eurasian Business Review, 7(1), 25-41. https://doi.org/10.1007/s40821-016-0044-6

Reuters Staff. (2016). Indonesia Eases Foreign Ownership Rules For Retail, Port Sectors. Retrieved February 2, 2021, from Reuters website: https://www.reuters.com/article/indonesia-investment-regulations-detailsidUSJ9N17P00W

Savrul, M., Incekara, A., \& Sener, S. (2014). The Potential of E-commerce for SMEs in a Globalizing Business Environment. Procedia - Social and Behavioral Sciences, 150, 3545. https://doi.org/10.1016/j.sbspro.2014.09.005

The World Bank. (2017). Indonesia's middle class vital for the country's future. Retrieved February 2, 2021, from https://www.worldbank.org/en/news/pressrelease/2017/12/04/indonesia-middle-class-vital-for-the-country-future 